\author{
Robert Sroka* \\ Kozminski University \\ Department of Entrepreneurship and Ethics in Business \\ e-mail: rsroka@kozminski.edu.pl
}

\title{
ESG Transparency on the Polish Capital Market
}

\begin{abstract}
The article presents the results of five years of research on transparency levels regarding the disclosure non-financial data by companies listed on the Warsaw Stock Exchange (WSE). The research was conducted as part of a project entitled "ESG analysis of companies in Poland". The goal of the project is to provide credible knowledge about the quality of environmental, social and corporate governance (ESG) data on the Polish capital market. The article mainly contains the results of a comprehensive analysis of how well the listed companies reported ESG related data in 2016. The five years of analysis enable us to show a change in the level of non-financial data disclosure between 2012 and $2016 .{ }^{1}$ The results of the research show that, from an investor's perspective, there is still a huge information gap on the Polish capital market, especially in the reporting of environmental and social data.
\end{abstract}

Keywords: ESG, SRI, business ethics, responsible investment, non-financial reporting, Polish capital market, transparency, ethical investment, Warsaw Stock Exchange

JEL Classification L21, M14, N20

\footnotetext{
"Dr Robert Sroka is the author of the project "ESG analysis of companies in Poland" and co-author of the research, the results of which are presented in this article.

${ }^{1}$ The main source of the data presented in this article is a report entitled Non-financial data reporting. Value for companies and investors, Polish Association of Listed Companies, Warsaw 2016.
} 


\section{Introduction}

Modern business models are different from those that prevailed in the last 40-50 years. Business models have undergone significant changes, and this can be confirmed by a distribution of components that determine the company's value. The studies that have been carried out for years by Ocean Tomo LLC show this process. In 1975, the value of the Standard \& Poors 500 Index was $83 \%$ determined by tangible assets. In 2015, the value of the index was $84 \%$ determined by intangible assets. ${ }^{2}$ The approach to the analyses of risks, values and business opportunities of intangible assets is different to the approach to analyses of tangible assets. The goal of this article is to present whether companies listed on the Warsaw Stock Exchange meet the expectations of responsible investors, taking into account the new component of corporate value and including ethical, social, environmental and corporate governance data in the investment process.

This article starts with an explanation of the Socially Responsible Investment (SRI) idea and a description of the main features of SRI strategies and the value of the SRI market. Next, regulatory changes are presented in terms of non-financial reporting. The main part of this article is dedicated to presenting the results of the project "ESG analyses of companies in Poland." The summary presents the perspective of investors that takes into account non-financial data in the financial analysis.

\section{Socially Responsible Investment}

More and more investors have started to include non-financial data in their investment process. This method of investment is called Sustainable and Responsible Investment (SRI). SRI is defined by the international Eurosif (European Sustainable Investment Forum) organization as a long-term oriented investment approach, which integrates ESG factors in the research, analysis and selection process of securities within the investment portfolio. It combines the fundamental analysis and engagement within an evaluation of ESG factors in order to better capture long-term returns for investors, and to benefit society by influencing the behavior of companies. ${ }^{3}$ Eurosif recognizes seven categories of SRI strategies: sustainability-themed investment; Best-in-Class investment selection; the exclusion of holdings from the investment universe; norm-based screening; the integration of ESG factors in financial analysis; engagement and voting on sustainability matters; and impact investing.

A sustainability-themed investment strategy relies on investing in themes or assets specifically related to sustainability, for example, clean energy, green technology or sustainable agriculture. Best-in-Class investment selection is defined as investing in sectors, companies or projects selected for positive ESG performance relative to industry peers.

\footnotetext{
${ }^{2}$ Source: Annual Study of Intangible Asset Market Value from Ocean Tomo, New York 2016.

${ }^{3}$ European SRI Study 2016, EUROSIF 2016, Brussels 2016, p. 9.
} 
The exclusion of holdings from the investment universe, in other words, negative screening, is described as the exclusion from a fund or portfolio of certain sectors, companies or practices based on specific ESG criteria. Norm-based screening consists of screening an investment against minimum standards of business practice based on international norms. The next strategy, called integration of ESG factors in financial analysis, is the systemic and explicit inclusion by investment managers of environmental, social and governance factors in traditional financial analysis. The strategy called engagement and voting on sustainability matters is implemented by the use of shareholder power to influence corporate behavior, including through direct corporate engagement (i.e. communicating with senior management and/or boards of companies), filing or co-filing shareholder proposals, and proxy voting that is guided by comprehensive ESG guidelines. The last strategy, called impact investing, is typically made in private markets, aimed at solving social or environmental problems, and including community investing, where capital is specifically directed to traditionally underserved individuals or communities, as well as financing that is provided to businesses with a clear social or environmental purpose. ${ }^{4}$

Every two years, Eurosif analyses the trends and capitalization of the SRI market in Europe. The results are presented in a report called the Eurosif SRI Study. The 7th edition of this Report from 2016 demonstrates sustained growth in SRI using different approaches. The most popular strategy is exclusion. In accordance with this strategy, assets under management (AuM) are estimated at over 10 trillion euro, covering $48 \%$ of the total of European professionally managed assets. It is important to underline the scope of the study. In total, 278 asset managers and asset owners with combined assets under management (AuM) of 15 trillion euro from 13 countries participated in the survey, representing a market coverage of $81 \% .^{5}$

Norm-based screening is the second biggest SRI approach, with over 5 trillion euro in assets under management and a steady growth rate of $40 \%$. The fastest growing strategy, with a growth of $385 \%$, is impact investing strategy ${ }^{6}$ although it has the lowest rate of capitalization, at a level of 98 billion euro. Engagement and Voting is the third most popular strategy in terms of AuM. The authors of the 2016 SRI Study highlight that it has a very strong link with fiduciary duty, as it is driven in large part by the view that stakeholders are stewards of assets, accountable to their beneficiaries for how they manage those assets. They also add that one of the keys to constructive company dialogue is developing a business case for change and keeping up a good level of interaction with companies. Therefore, investors manage assets worth 4.2 trillion euro included in their investment policy commitment to engagement and voting.

\footnotetext{
${ }^{4} 2014$ Global Sustainable Investment Review, Global Sustainable Investment Alliance, Washington DC, p. 5. ${ }^{5}$ This estimation is based on EFAMA's 2014 estimate of the total assets under management (AuM) in Europe, presented in its 8th Annual Review, Asset Management in Europe from April 2015, available at: http://www. efama.org/Publications/Statistics/Asset\%20Management\%20Report/150427_Asset\%20Management\%20Report \%20 2015.pdf (accessed: 15.01.2018).

${ }^{6}$ European SRI Study..., pp. 7-8.
} 
Sustainability-themed investment is more and more popular among European investors. European sustainability-themed assets are estimated at 145 billion euro, and they are found in such categories as renewable energy, energy efficiency, sustainable transport, the building sector, land use, forestry, agriculture, water management or waste management.

From the perspective of this article, besides the norm-based screening strategy, the key approaches are Best-in-Class and ESG integration strategies. Those three strategies require high quality, systematically collected non-financial data. By choosing the Best-in-Class strategy, investors have the opportunity to pick those companies that have the best ESG score in a particular sector. Between 2013 and 2015, Best-in-Class grew by $40 \%$, with AuM reaching almost 493 billion euro. Through the use of the ESG integration strategy, investors have a better picture of investment targets. According to the 2016 SRI Study, the market of AuM in line with this strategy is worth 2.6 trillion euro. ${ }^{8}$

Each of the abovementioned SRI strategies needs ESG data to be fulfilled. The significance of the growth in the SRI market is also shown by the statistic delivered by the Principles of Responsible Investment (PRI). PRI is the world's leading proponent of responsible investment, supporting its international network of investors in incorporating ESG factors into their investment and ownership decision. PRI was founded in 2006 with 10 partners. In 2017, PRI had over 1500 signatories managing more than US\$ 60 trillion.

Each member of the PRI is obligated to sign the Six Principles. The signatories commit to the following: Principle 1 - We will incorporate ESG issues into the investment analysis and decision-making process; Principle 2-We will be active owners and incorporate ESG issues into our ownership policies and practices; Principle 3 - We will seek appropriate disclosure on ESG issues by the entities in which we invest; Principle 4 - We will promote the acceptance and implementation of the Principles within the investment industry; Principle 5 - We will work together to enhance our effectiveness in implementing the Principles; Principle 6 - We will each report on our activities and progress towards implementing the Principles. ${ }^{9}$

Investors implementing the abovementioned Principles or SRI strategies need non-financial information from companies. According to the report Tomorrow's Investment Rules 2.0, prepared by Ernst \& Young (EY), 70\% of global and 80\% of European investors consider integrated reports to be essential or important in making investment decisions. It is worth mentioning that in 2015, the percentage of investors who considered integrated reports to be a key source for making investment decisions increase by $10 \%$ compared to 2014. The number of investors who think that ESG factors are important regardless of the sector has risen by $50 \%$ and now stands at over $61 \% .^{10}$

Hence, more and more companies have decided to publish reports with non-financial data or integrated reports that cover both financial and ESG information. Those companies which don't improve their practices in terms of ESG transparency may lose the opportunity to attract responsible investors.

\footnotetext{
${ }^{7}$ European SRI Study..., p. 18.

${ }^{8}$ European SRI Study ..., pp. 12-22.

${ }^{9}$ Source: https://www.unpri.org/about/the-six-principles (accessed: 28.01.2018).

${ }^{10}$ EY Tomorrow's Investment Rules 2.0, EY, London 2016.
} 


\section{Regulations}

Since 2014, especially in the European Union and in Poland, there are significant hard law and soft law changes in terms of financial and non-financial data reporting. In Poland, the Accounting Act was amended to comply with the provision of Directive 2014/95/EU of the European Parliament and the Council of 22 October 2014 on non-financial disclosure. ${ }^{11}$ This Directive is applicable to two groups of entities. One of them is wider and covers the majority of companies listed on the regulated market. Such entities are obligated to add to their corporate governance statements a description of their diversity policy that applies to their administrative, management and supervisory bodies. The second group includes large public-interest entities, i.e., those that fulfil all of the following conditions: a) the entity is an issuer whose financial instruments are listed on a regular market or a credit institution or an insurance agency or any other institution considered to be a public-interest unit by the state; b) it has a balance sheet total of at least EUR 40 million or sales revenue of at least EUR 40 million on the balance day or for the previous financial year; c) it employs, on average, at least 500 persons per financial year. These entities have to prepare an extended statement with non-financial information. The statement has to include information that is essential to understand the company's development, results and standing, as well as its environmental, social and labor-related impacts. It should consist of a short description of its policies covering particular ESG areas, results and policy implementation, the main risks linked to the abovementioned issues and the management of such risks, together with key non-financial indicators.

At the beginning of 2016, the amended Good Practices of Companies Listed on the Warsaw Stock Exchange entered into force..$^{12}$ Since 3 July 2016, new requirements of the Market Abuse Regulation (MAR) have been applied. These changes have significantly influenced the existing reporting rules for listed companies and changed the approach to reporting routines. To report the required information correctly, companies must conduct a thorough analysis of the surrounding environment and their own cooperation. The responsibility for identifying which information is material, price-forming and valuable for the shareholders, stakeholders and regulators is shifted onto companies. This is a huge challenge if we consider how Polish companies have so far been engaged in non-financial data reporting and sustainable development. This will be presented below.

\section{ESG data on Polish capital market}

In 2012, the project "ESG Analysis of Companies in Poland" was launched by three organizations: the Polish Association of Listed Companies, Global Engagement Services (GES) and the consulting firm Crido Taxand. Before the fifth edition of the project, Crido Taxand

\footnotetext{
${ }^{11}$ European Union Official Journal L330 of 15.11.2014.

12 Source: https://www.gpw.pl/pub/GPW/o-nas/DPSN2016_EN.pdf.
} 
was replaced by EY. The main goal of the project was to increase the level of transparency of non-financial reporting by companies listed on the Warsaw Stock Exchange. As shown above, ESG data is becoming more and more essential for investors and analysts in their investment decision making. The authors of the project wanted to provide investors and analysts with credible, non-financial data about Polish listed companies. The project also reflects the legislative changes concerning non-financial reporting.

\section{Method of evaluation}

The analyzed companies were verified regarding the transparency of disclosed data concerning environmental protection, social responsibility and corporate governance. In all three categories, the companies had to meet defined criteria, both general and, as far as environmental protection and social responsibility are concerned, sectoral, in order to achieve a satisfactory evaluation. The GES Risk Rating was used for the evaluation. It analyses companies' management of Environmental, Social and Corporate Governance (ESG) factors. The analysis is based on international norms on ESG issues in accordance with the Principles for Responsible Investment. The GES Risk Rating evaluates both the companies' preparedness (through management systems etc.) as well as performance through a number of criteria and sub-criteria. The final score is calculated as an average from applicable criteria. The criteria are based on sub-criteria which reflect the quality of the information the company discloses in relation to the given issues.

In terms of the environmental area, the GES Risk Rating evaluates the quality and implementation of environmental management system as well as the management of specific aspects. On the preparedness level, the method asses such data as: organization and routines; policy and programs; external verification; environmental reporting; and supplier evaluation. On the performance level, the method asses such data as: greenhouse gases; energy use; use of water resources; travel management; remediation; project development; hazardous waste; emissions to air; plus 8 more criteria. The social area was divided into three parts called employees, community, and suppliers. Concerning the employee part, the following criteria are listed: discrimination; freedom of association; Health \& Safety; working hours and wages; plus five more criteria. In terms of the community area, it focuses on the use of security forces; corruption and two more criteria. Moreover, in terms of suppliers, the method includes a code of conduct for suppliers; the management system and program for supplier and carrying out an evaluation. The GES Risk Rating also focuses on the area of corporate governance, which is divided into three parts: 1. Board management and control (Audit/Compensation/Nomination Committees; Board composition and independence; Boardroom diversity); 2. Shareholder rights (equal voting rights; ownership transparency); 3. Transparency and incentive (audit firm costs; CEO compensation; governance reporting).

All criteria are derived from international norms.

Company rating method by points: 
Table 1. GES Risk Rating method

\begin{tabular}{|l|l|l|l|l|}
\hline $\begin{array}{c}\text { Point range } \\
\text { in the } \\
\text { environmental } \\
\text { area (E) }\end{array}$ & $\begin{array}{c}\text { Point range } \\
\text { in the social } \\
\text { and corporate } \\
\text { governance areas } \\
\text { (S and CG) }\end{array}$ & Rating & \multicolumn{1}{|c|}{ Level } & \multicolumn{1}{|c|}{ Description } \\
\hline $0-0.29$ points & $0-0.19$ points & $\mathrm{C}$ & $\begin{array}{l}\text { Low/No informa- } \\
\text { tion disclosure }\end{array}$ & $\begin{array}{l}\text { No information or total } \\
\text { failure }\end{array}$ \\
\hline $0.3-0.74$ points & $02-0.49$ points & $\mathrm{c}+$ & Relatively low & $\begin{array}{l}\text { Indication of company } \\
\text { strategy }\end{array}$ \\
\hline $0.75-1.19$ points & $0.5-0.79$ points & $\mathrm{b}-$ & Medium & Extensive policy \\
\hline $1.2-1.79$ points & $0.8-1.19$ points & $\mathrm{B}$ & Medium & $\begin{array}{l}\text { Policy }+ \text { programme } \\
\text { or policy + management } \\
\text { system }\end{array}$ \\
\hline $1.8-2.24$ points & $1.2-1.49$ points & $\mathrm{b}+$ & Relatively high & $\begin{array}{l}\text { Policy + programme } \\
+ \text { management system }\end{array}$ \\
\hline $1.25-2.69$ points & $1.5-1.79$ points & $\mathrm{a}-$ & Relatively high & Progress evaluation \\
\hline $2.7-3$ points & $1.8-2$ points & A & High & External verification \\
\hline
\end{tabular}

Source: P. Sergeto, K. Burger, M. Pitura, Non-financial data reporting of the listed companies in 2016 [in:] Non-financial data reporting. Value for companies and investors, ed. R. Sroka, Polish Association of Listed Companies, Warsaw 2017, p. 12.

In the GES Risk Rating method, "policy” means declaring a company's position regarding a specific aspect, for example, discrimination. "Program" normally refers to a plan with detailed goals and measures designed to fulfill intentions, written out in a policy. Other important features of a program are risk analysis training of employees. An identified program must include at least one of the following features: 1) employee training, 2) breakdown of policy into detailed goals, 3) direct investments or 4) analysis of what measures need to be taken. "Management system" means the organization and routines deployed in order to ensure that a program is carried out as intended and/or to deal with incidents/issues that are not compliant with the policy. An example of small management can be a "whistle-blower" function. "Progress evaluation" is part of company reporting that clarifies to what extent policies and goals have been reached. Performance data means information that makes it possible to evaluate whether a company is making progress in reaching its goals. Examples of performance data might include: lost work hours, the share of employees that are members of a union, or the number of employees that are covered by a collective bargaining agreement. The last stage - verification - is a statement from a party other than the company itself verifying the information in the company's reporting concerning specific assessment criteria. For instance, if a company claims that union relations have improved, it would be desirable if some other part evaluated this statement.

The main sources of the GES Risk Rating analyses are the company's Annual Report, other official documents and its website. Additionally, news coming from financial and business sources, governmental regulatory and non-governmental organizations, press agencies, trade journalists as well as online information providers might be taken into consideration. 
Being given an appropriate assessment in the project allows companies to get a sector benchmark and provides the analytical basis to support financial decision-making, such as the construction of portfolios or active engagement with underperformers.

\section{Range of analysis}

In 2016, the level of non-financial data reporting of companies listed on the Warsaw Stock Exchange (WSE) was analyzed for the fifth time. The analysis covered the companies listed on the Main Market of the Warsaw Stock Exchange as of June 30, 2016 - altogether, 483 business entities were analyzed.

Thanks to the application of the same evaluation method, it is possible to make comparisons and draw conclusions. However, the list of the companies listed on the WSE has changed during last five years. To provide the same scope of comparative analysis, two groups of companies will be presented:

(1) Companies listed on the Main Market - the group consists of companies that were analyzed in both 2012 and 2016, which is 408 companies altogether.

(2) Companies that employ over 500 employees - the group consists of companies (public interest entities) which, under the changes in the Accounting Act in 2017, are obligated to report non-financial data. It includes 128 companies that fulfilled the criterion in 2015 and were listed in both 2012 and 2016.

To conclude, this article will present a comparative analysis of three main groups of companies: the first group - 483 companies representing the Main Market of the WSE in 2016; the second - 408 companies listed on the Main Market of the WSE in both 2012 and 2016; the third - 128 companies which, under the Accounting Act, are obligated to report non-financial data.

The analysis will be divided into three main parts. The first area will include the results of the analysis in the social area. The second area will be the environmental area. And the last part will be dedicated to the corporate governance area.

\section{Overview of the results for the Main Market of the Warsaw Stock Exchange}

Before the results of particular areas of analysis are presented, the results of the analysis for 483 companies analyzed in 2016 will be shown.

Quantitative and percentage breakdown of companies according to their total score in each of the ESG categories.

In terms of the social responsibility area, none of the companies scored 'a' or 'a-', which means that none of the companies shows a high or relatively high level of reporting in this part. 3 companies, representing $0.6 \%$ of the total were given the satisfactory score ' $b+$ '. $3.5 \%$ of companies received a ' $b$ ' while a further $6.6 \%$ achieved a 'b-'. $16 \%$ of companies were 
given a 'c+'. 354 companies, representing $73.3 \%$ of the total, received the lowest score, 'c', which means that the companies either present little information or they do not disclose any information at all in the area of social responsibility. Regarding these 354 companies, 57\% of them revealed little information and $43 \%$ gave no information on social responsibility.

Table 2. Quantitative and percentage breakdown of companies according to their total score in each of the ESG categories

\begin{tabular}{|c|c|c|c|c|c|c|}
\hline Level & \multicolumn{2}{|c|}{ Social responsibility } & \multicolumn{2}{c|}{$\begin{array}{c}\text { Environmental } \\
\text { management }\end{array}$} & \multicolumn{2}{c|}{ Corporate governance } \\
\hline a & 0 & $0 \%$ & 0 & $0 \%$ & 1 & $0.2 \%$ \\
\hline a- & 0 & $0 \%$ & 0 & $0 \%$ & 39 & $8.1 \%$ \\
\hline b+ & 3 & $0.6 \%$ & 3 & $0.6 \%$ & 212 & $43.9 \%$ \\
\hline b & 17 & $3.5 \%$ & 29 & $6 \%$ & 202 & $41.8 \%$ \\
\hline b- & 32 & $6.6 \%$ & 28 & $5.9 \%$ & 16 & $3.3 \%$ \\
\hline c + & 77 & $16 \%$ & 104 & $21.5 \%$ & 4 & $0.8 \%$ \\
\hline c & 354 & $73.3 \%$ & 319 & $66 \%$ & 9 & $1.9 \%$ \\
\hline
\end{tabular}

Source: P. Sergeto, K. Burger, M. Pitura, Non-financial data reporting of the listed companies in 2016 [in:] Non-financial data reporting. Value for companies and investors, ed. R. Sroka, Polish Association of Listed Companies, Warsaw 2017, p. 12.

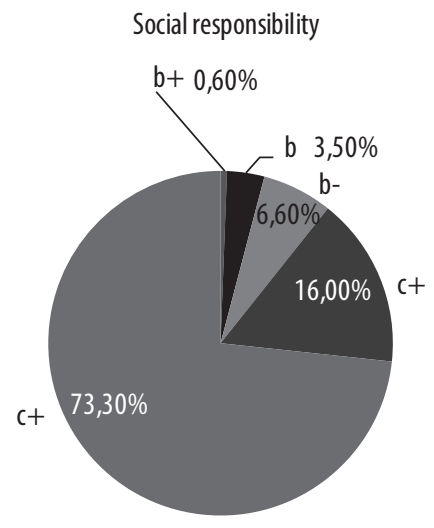

Graph 1. The results of the ESG analyses in terms of social responsibility

Source: P. Sergeto, K. Burger, M. Pitura, Non-financial data reporting of the listed companies in 2016 [in:] Non-financial data reporting. Value for companies and investors, ed. R. Sroka, Polish Association of Listed Companies, Warsaw 2017, p. 13.

In terms of environmental management, none of the analyzed companies scored 'a' or 'a-', which means that none of the companies presents a high or relatively high level of reporting in this area. 3 companies, representing $0.6 \%$ of the analyzed group, achieved the satisfactory score of ' $b+$ '. $6 \%$ of the companies scored ' $b$ ' and $5.9 \%$ received score 'b-'. The reporting level of $21.5 \%$ of companies was assessed as ' $c+$ '. 319 companies, $66 \%$ of the total, were given the lowest score, 'c', which means that these companies either disclose little information on the 
environment or they do not disclose any information in this area at all. $32.3 \%$ of the 319 companies publish little information while the rest disclose no information at all on their environmental management.

Environmental management

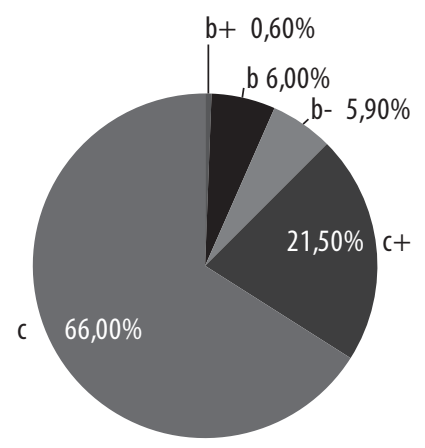

Graph 2. The results of the ESG analyses in terms of environmental management

Source: P. Sergeto, K. Burger, M. Pitura, Non-financial data reporting of the listed companies in 2016 [in:] Non-financial data reporting. Value for companies and investors, ed. R. Sroka, Polish Association of Listed Companies, Warsaw 2017, p. 13.

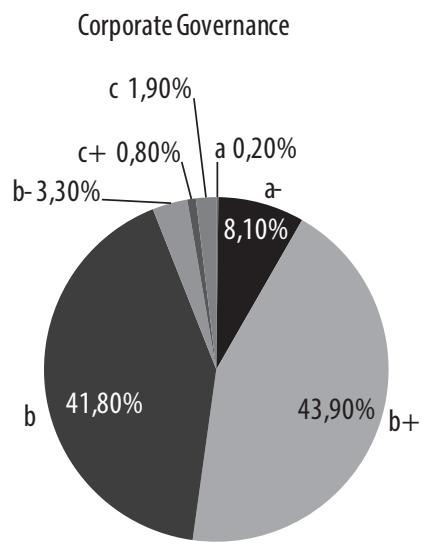

Graph 3. The results of the ESG analyses in terms of corporate governance

Source: P. Sergeto, K. Burger, M. Pitura, Non-financial data reporting of the listed companies in 2016 [in:] Non-financial data reporting. Value for companies and investors, ed. R. Sroka, Polish Association of Listed Companies, Warsaw 2017, p. 14. 


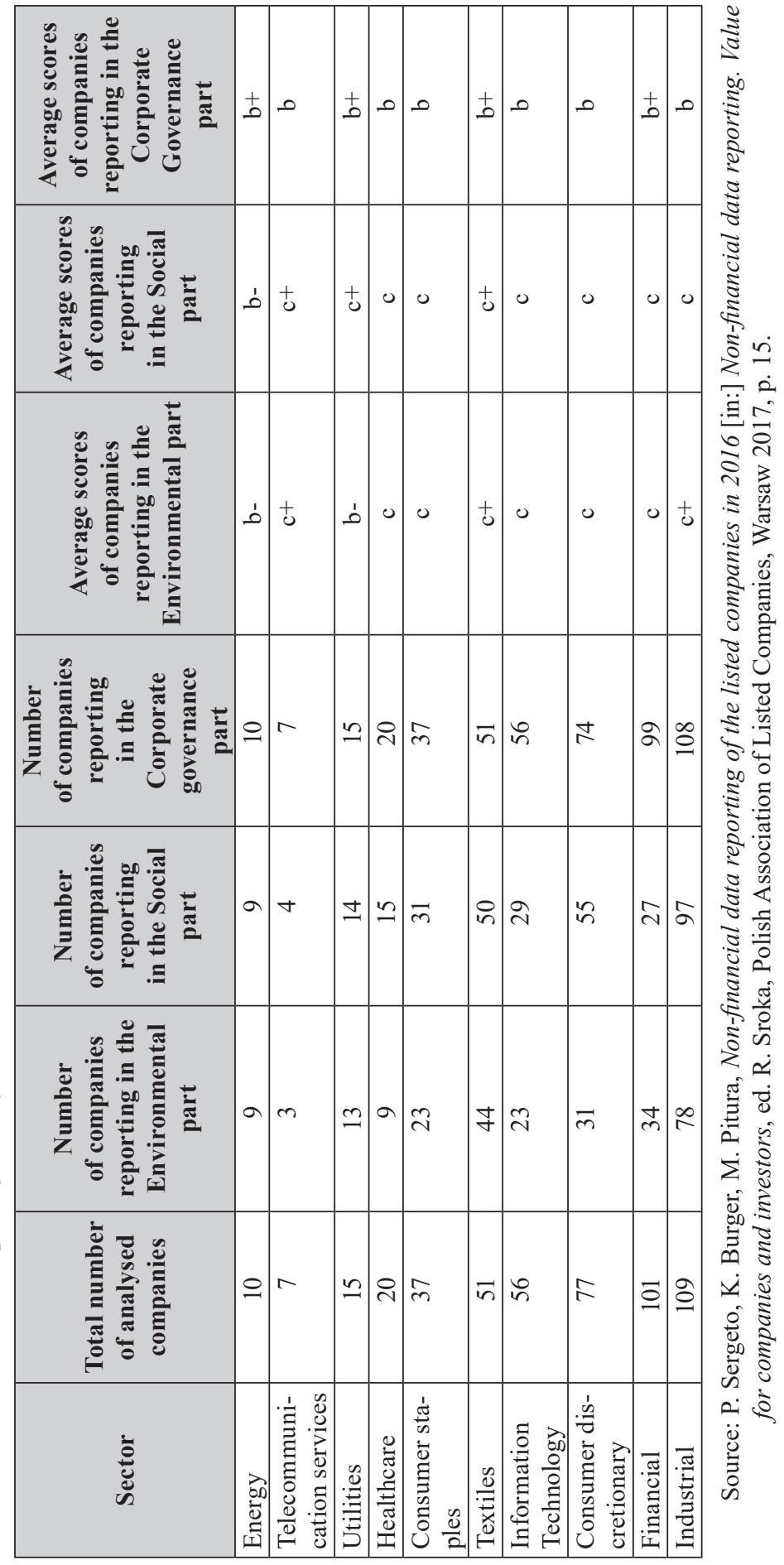


Corporate governance is an area with a high level of transparency. $52 \%$ of the analyzed companies show a relatively high level of reporting and scored ' $a$-' and ' $b+$ '. $41.8 \%$ of the companies were given a ' $b$ ' and 3.3\% were given ' $b-$ '. 13 companies received the rating of 'c+' or 'c', which means that $2.7 \%$ of companies publish little or no corporate governance information.

Non-financial data reporting level by sectors

The GES Risk Rating also allows us to show the results divided by sector. Taking into account the results of all three parts of the analysis, the utilities and energy sectors received high results. $90 \%$ of companies from the utilities sector and $87 \%$ of companies from the energy sector, respectively, report on environmental issues, and $90 \%$ of companies from the utilities sector and $93 \%$ of companies from the energy sector disclose information on social responsibility. All the companies in these sectors publish corporate governance information. However, only 25 analyzed companies belong to these sectors. The textiles sector, covering 51 companies in the analysis, achieved relatively good scores as well. The level of ESG reporting by companies in this sector reached $86 \%, 98 \%$ and $100 \%$ for each of the respective parts of the analysis. The lowest level of environmental reporting is presented by companies in the telecommunication services, healthcare, IT, consumer discretionary and financial sectors. The situation looks similar in terms of social responsibility reporting. Only $36.6 \%$ of companies from the telecommunication services, IT and financial sector publish information on this topic.

The results of the 2016 analysis show that the level of environmental and social data reporting is still low. In most cases, companies limit their reporting to statements on compliance with laws and regulations, information about ISO 14001 certification, their environmental policy and the implementation of an environmental management system. Information about the company's actual impact on the environment is rarely published. Among the companies covered, $12.6 \%$ (61 out of 483 companies) report on criteria related to greenhouse gases emission, $20.9 \%$ (99 out of 473 companies) report energy use, $24.1 \%$ (37 out of 153 ) water consumption, and 19.3\% (54 out of 280) waste generation. Only $14.3 \%$ of the analyzed companies (69 out of 483) publish information on their environmental requirements towards suppliers. The companies most often describe their occupational health and safety activities $36.2 \%$ (175 out of 483 ) as well as community involvement initiatives $45 \%$ (141 out of 312 companies). $24 \%$ of the analyzed companies publish information on fighting discrimination. 17.9\% (77 out of 431) report on corruption requirement towards suppliers.

\section{Social area}

The level of social data reporting is still very low. $63 \%$ of the 408 companies listed on the Main Market of the Warsaw Stock Exchange in 2012 and 2016 published more information on these aspects in 2016 than they did in 2012. However, the average increase is only 0.2 points. Among the 128 analyzed companies which are required to disclosure non-financial data according to the Accounting Act, $80 \%$ improved their reporting of social data between 
2012 and 2016. The average increase is 0.24 points. $97 \%$ of companies still do not publish enough social or labor-related data to fulfill the new requirements of the Accounting Act in this area. $42 \%$ of the analyzed companies reported health and safety issues at a satisfactory level, meaning that they showed indications of relevant policies and management systems being in place. Data in relation to freedom of association is shown by $18 \%$ of the checked companies. 13\% of companies employing over 500 employees reveal information about their wage policy. Human rights is the area with the lowest result. Eleven companies provided information about their policy on human rights and two companies described a management system, but none of them presented a satisfactory level of reporting relating to indicators showing the results of the implementation of their human right policy. One of the analyzed companies published information about risk management in relation to combatting child labor. 72 companies showed a satisfactory or high level of reporting on how they manage risks lined to forced labor.

Polish companies should increase transparency in terms of human rights. In particular, they should publish more information about their approach to business practices related to forced and child labor. According to a study from the Walk Free Foundation, as much as two-thirds of modern slavery occurs in Asian countries. So, the information published by these companies should show their approach to this issue in the supply chain, among other areas. According to the same study, in Poland, there are approximately 180,000 slaves. This is the worst score in the whole of the European Union, and it puts Poland in $24^{\text {th }}$ place in the ranking that shows the estimated proportion of slaves compared to the total population. ${ }^{13}$

Information about the reporting of labor conditions by companies is becoming more and more crucial for investors. One of the reasons is the growing predominance of employees on the labor market. Karol Raźniewski and Malgorzata Fiedorczuk, EY experts in the labor market, underline that Poland will face a significant decline in the population in the coming years. By 2020, the population will decrease by about 280,000 compared to 2015 , and by almost one million by 2030 . As a result, the number of people of working age will also fall. According to studies by the Central Statistical Office in Poland, in June 2016 alone, employers submitted 146,000 job offers to employment offices, which is $21.7 \%$ more than in June 2015. The gross remuneration in the corporate sector was $5.3 \%$ higher than in 2015. Recent studies clearly show that the situation of employees on the labor market has improved and we are getting closer to an "employee market" than an "employer market". In 2015, over $40 \%$ of the companies declared that they had problems with staffing. Raźniewki and Fiedorczuk indicate the ability to innovate as one of the main reason why companies should increase transparency in terms of the labor area, and investors should take into consideration this kind of information when making investment decisions. In the current economy, innovation is a necessary condition to build market position and maintain a competitive advantage. It is important to note that the only asset a company has that enables it to be innovative is its personnel. The ability to be innovative does not determine which company is the industry leader today but which company has a chance to become one in the coming years..$^{14}$

\footnotetext{
${ }^{13}$ The Global Slavery Index 2016, Walk Free Foundation, Netherlands 2016.

${ }^{14}$ K. Raźniewski, M. Fiedorczuk, HR area - which indicators to report and why [in:] Non-financial data reporting. Value for companies and investors, Polish Association of Listed Companies, Warsaw 2016, pp. 40-42.
} 


\section{Environmental data}

$50 \%$ (206 out of 428) of the analyzed companies did not change their approach towards environmental data reporting between 2012 and 2016. In 2016, less info was available about environmental management at $14 \%$ of companies than five years ago. During the same period, $36 \%$ of companies improved the level of information to their stakeholders on how they manage environmental matters. The average increase is 0.3 points. Among the companies which are obligated to report non-financial data according to the Accounting Act (128 analyzed companies), 59\% of companies improved their reporting practices in terms of environmental data reporting. The average increase is 0.35 points. $20 \%$ of these companies meet the requirements of the Accounting Act.

It is challenging for companies to meet the legislative requirement, not only those imposed by the Accounting Act. Kłaczyńska, Pizoń and Guzkowski, who commended the presented results, underline that environmental regulations are one of the most changing areas of law. In the case of Polish law, in 2015 alone, there were many changes to the regulations on renewable energy sources (the act entered into force and was amended), the provisions on the recycling of end-of-life vehicles, the management of waste electrical and electronic equipment, regulations on the manufacturing and making available on the market of active substance and biocidal products, the Environmental Protection Law Act and the Act on Greenhouse Gases and Other Substances Emissions Management System or the Anti-Smog Act. Companies which are obligated to report environmental data should remember that one of the assumptions of preparing the report is that it follows the data materiality rule. It means that a report with such data should cover issues that can rationally be considered important, taking into account the company's environmental perspective.

Kłaczyńska, Pizoń and Guzkowski notice that a significant part of areas that the new regulations cover overlaps with indicators that are used in the evaluation of particular aspects within specific categories in accordance with an international reporting standard, such as the Global Reporting Initiative. For instance, the environmental category includes the "energy" aspect, which encompasses a few indicators related to energy consumption. The "energy consumption within the organization" indicator requires the amount of energy used presented in joules and a description of fuel types. Is should also be specified what part of the energy consumed comes from renewable energy sources. Additionally, the "energy intensity" indicators require an energy intensity ratio, interpreted in a similar way as in the national legislation but also including additional types of energy. The "reductions of energy consumption" requires that the amount of reductions in energy consumption be achieved as a direct result of conservation and efficiency initiatives. The Global Reporting Initiative indicators correspond with the data already is collected in line with the provision of the Energy Law, the Renewable Energy Sources Law or the Energy Efficiency Act. Similar synergies can be observed in the aspect related to emissions. The indicator of the Global Reporting Initiative requires that the company present data that it is already necessary to report under the Act of the Greenhouse Gases Emissions Trading Scheme and the Environmental Protection Law Act. ${ }^{15}$

\footnotetext{
${ }^{15}$ K. Kłaczyńska, G. Pizoń, J. Guzkowski, Non-financial data reporting on environmental aspects - challenges in the evolving legal reality [in:] Non-financial data reporting. Value for companies and investors, Polish Association of Listed Companies, Warsaw 2016, pp. 36-38.
} 


\section{Corporate governance data}

According to the results of the analysis of the project "ESG Analysis of companies in Poland", the level of corporate governance reporting worsened in 55\% of companies between 2012 and 2016. The trend is even worse among companies that employ over 500 employees (128 companies analyzed) where the results are poorer in $66 \%$ of companies. The average decrease is 0.2 points. Companies are less transparent in their corporate governance reporting and this is mainly linked to the lack of consistency in their reporting about $\mathrm{Su}-$ pervisory Board members' independence and the failure to publish biographies for Management Board members. When compared to environmental and social reporting, the level of information disclosed in the corporate governance area is still definitely higher. However, historically, this area has been regulated the most strongly by the Warsaw Stock Exchange as being good practice and it should guarantee stable and responsible management. That's why a decreasing trend in the transparency level in this area is worrying.

Corporate governance is a wide reporting area. In the light of the Accounting Act, in terms of non-financial reporting, there is one topic that should be underlined. This topic is linked to a new understanding of corporate governance that is combined with compliance and ethics, which refer to fighting corruption and bribery. Editors International standard ISO 37001 Anti-bribery management systems, points out that bribery is a widespread phenomenon. It raises serious social, moral, economic and political concerns, undermines good governance, hinders development and distorts competition. It erodes justice, undermines human rights and is an obstacle to the relief of poverty. It also increases the costs of doing business, introduces uncertainties into commercial transactions, increases the costs of goods and services, diminishes the quality of products and services, which can lead to loss of life of poverty, destroys trust in institutions, and interferes with the fair and efficient operation of markets. ${ }^{16}$ Corruption and bribery are still important issues also in Poland. According to the report published annually by Transparency International, Poland ranks $30^{\text {th }}$ among the least corrupt countries. ${ }^{17}$ It is a quite good position, but it is worth noticing that many companies still think the issue of corruption is common in their everyday operations. According to the $14^{\text {th }}$ Global Fraud Survey "Corporate misconduct - individual consequences" carried out by EY, 34\% of Polish respondents think that corrupt practices are widespread in Polish business. Additionally, 26\% of respondents are of the opinion that offering gifts, entertainment or money can be justified if it aims at helping the company survive in the economic crisis. ${ }^{18}$ Bribery is not only a Polish issue, it is a global challenge. Therefore, the preferred solution for companies to improve their management and report practice in terms of counteracting corruption could be the implementation of ISO 37001. This norm specifies requirements and provides guidance for establishing, implementing, maintaining, reviewing and improving an anti-bribery management system. The requirements of ISO 37001 are generic and can be applicable to all organizations regardless of type, size and nature of the activity.

\footnotetext{
${ }^{16}$ International Standard ISO 37001 Anti-bribery Management System, International Organization of Standardization, Genève 2016, p. VI.

${ }^{17}$ Source: https://www.transparency.org/news/feature/corruption_perceptions_index_2016.

${ }^{18}$ Corporate Misconduct - Individual Consequences Global Enforcement Focuses the Spotlight on Executive Integrity. 14th Global Fraud Survey 2016, EY 2016.
} 


\section{Summary - the financial eturn from being transparent is not enough}

This article starts from the investors' perspective and this point of view finishes this article. The data gathered during the project "ESG Analysis of Companies in Poland" are used by financial analysts to find a correlation between non-financial and financial performance. Based on the results for the 128 companies which will obligated to report non-financial data, Piotr Kaźmierkiewicz, analyst at Central Brokerage House PEKAO, created two portfolios: a portfolio of companies considered as transparent (the highest $20 \%$ of the ESG scores) and a portfolio of non-transparent companies (the lowest $20 \%$ of the ESG scores). The division of companies was made based on the average ESG score received by companies over the five editions of the project.

The analysis of results shows that the transparency portfolio reached lower average monthly return rates, although the average of the non-transparent portfolio was not statistically significant. What was significant was the volatility variation of the monthly return rates of the portfolios. Additionally, the transparency portfolio included companies that were significantly larger. According to Kaźmierkiewicz, this indicates that it is possible to diversify portfolio risk based on the level of non-financial data disclosure. However, the dispersal of portfolio risk may lead to a deterioration of the expected return rate. This dependence is consistent with the portfolio theory, according to which a portfolio with a lower risk should be characterized by a lower return rate. The cumulative return rate of the portfolio comprising companies with the highest ESG scores in 2012-2016 was lower than that of the non-transparent portfolio. Both return rates of the transparency and non-transparency portfolios were simultaneously higher than the return rates of the WIG index (the main index on the Warsaw Stock Exchange). The advantage of the wider market mixed with its weakness up until the second half of 2015, when the companies with high ESG scores more visibly started to establish their advantage over the WIG index. The final difference between the transparent portfolio and the WIG index over four years was $16.2 \mathrm{pp}$ (3.6 pp on an annual average), and this difference is statistically relevant. It shows that the so-called transparency cost, a decrease in return rates of companies with a high quality of non-financial data disclosure, is not present on the Polish market. ${ }^{19}$

Kaźmierkiewicz also notes that the results of the fifth edition of the "ESG Analysis of Companies in Poland" project confirm that information asymmetry on the capital market depends largely on the level of non-financial data reporting. Considering the issue from the Warsaw Stock Exchange perspective, it may seem to be beneficial for investors operating on the WSE to take into account non-financial data. The analysis of non-financial data allows for a more accurate investment risk assessment and thus a better valuation of a given company. ${ }^{20}$

\footnotetext{
${ }^{19}$ P. Kaźmierkiewicz, Five years of building transparency [in:] Non-financial data reporting. Value for companies and investors, Polish Association of Listed Companies, Warsaw 2016, pp. 64-65.

${ }^{20}$ Ibidem, p. 66.
} 
From the investor perspective, there is still a huge information gap on the Polish capital market, especially in the reporting of environment and social data. However, from the companies' perspective, they do not see any real interest in their non-financial data from investors, especially from Polish investors.

The results of the fifth edition of the 'ESG Analysis of Companies in Poland' project shows that companies listed on the Warsaw Stock Exchange should increase their practices in terms of disclosing non-financial data because of the four main reasons presented in this article: investors; regulations; stakeholders' expectations; and internal needs.

\section{References}

8th Annual Review, Asset Management in Europe, EFAMA, Brussels 2015, available at: http://www. efama.org/Publications/Statistics/Asset\%20Management\%20Report/150427_Asset\%20Management $\% 20$ Report $\% 202015$.pdf.

2014 Global Sustainable Investment Review, Global Sustainable Investment Alliance, Washington DC, 2015.

Annual Study of Intangible Asset Market Value, Ocean Tomo, New York 2016.

Corporate Misconduct - Individual Consequences Global Enforcement Focuses the Spotlight on Executive Integrity. 14th Global Fraud Survey 2016, EY 2016.

European SRI Study 2016, EUROSIF 2016, Brussels 2016.

European Union Official Journal L330 of 15.11.2014.

EY Tomorrow's Investment Rules 2.0, EY, London 2016.

International Standard ISO 37001 Anti-Bribery Management System, International Organization of Standardization, Genève 2016.

Kaźmierkiewicz P., Five years of building transparency [in:] Non-financial data reporting. Value for companies and investors, Polish Association of Listed Companies, Warsaw 2016.

Kłaczyńska K., G. Pizoń, J. Guzkowski, Non-financial data reporting on environmental aspects - challenges in the evolving legal reality [in:] Non-financial data reporting. Value for companies and investors, Polish Association of Listed Companies, Warsaw 2016.

Principles for Responsible Investment, source: https://www.unpri.org/about/the-six-principles.

Raźniewski K., M. Fiedorczuk, HR area - which indicators to report and why [in:] Non-financial data reporting. Value for companies and investors, Polish Association of Listed Companies, Warsaw 2016.

Sergeto P., K. Burger, M. Pitura, Non-financial data reporting of the listed companies in 2016 [in:] Non-financial data reporting. Value for companies and investors, ed. R. Sroka, Polish Association of Listed Companies, Warsaw 2017, pp. 12-27.

The Global Slavery Index 2016, Walk Free Foundation, Netherlands 2016. 
